6. Collignon P J, Graham E, Dreimanis DE. Reuse in sterile sites of singleuse medical devices: how common is this in Australia? Med $J$ Aust 1996;164:533-536.

7. Comis J. Reusing Single-Use Cardiac Catheters. Dimensions 1991;October: 32-34.

8. Association for the Advancement of Medical Instrumentation. Design, Testing, and Labeling Reusable Medical Devices for Reprocessing in Health Care Facilities: $A$ Guide for Device Manufacturers. Report no. 12. Arlington, VA: AAMI; 1995.

9. Morrissey RF. Bioburden: a rational approach. In: Gaughran ERL, Morrissey RF, eds. Sterilization of Medical Products, vol. II. 2nd ed. Montreal, Quebec, Canada: Multiscience Publications; 1981:11-33.

10. Morrissey RF, Phillips CB. Sterilization Technology: A Practical Guide for Manufacturers and Users of Health Care Products. New York, NY: VanNostrad Reinhold; 1993:518.

11. American Public Health Association. Standard Methods for the Examination of Water and Wastewater. 19th ed. Washington, DC: APHA; 1995:9-31, 9-38.
12. United States Pharmacopeia. 23rd ed. Rockville, MD: United States Pharmacopeial Convention; 1995:1847-1849, 1976-1981

13. Penna TC, Machoshvili IA, Taqueda ME. Thermal resistance of Bacillus stearothermophilus spores on strips previously treated with calcium. PDA I Pharm Sci Technol 1996;50:227-237.

14. Ferraz CA. STERRAD opte pelo futuro. Enfoque 1995;21:12-15.

15. Cassola MA, Ishsaki E, Ferraz CA, Vessoni Penna TC. Esterilização de artigos médico hospitalares por plasma de peróxido de hidrogénio. Laes \& Haes 1997;19:88-100.

16. Alfa MJ. Plasma-based sterilization. The challenge of narrow lumens. Infection Control \& Sterilization Technology 1996;19-24.

17. Alfa MJ, Sitter DL. In-hospital evaluation of orthophthaladehyde as a high-level disinfectant for flexible endoscopes. I Hosp Infect 1994; 26:15-56.

18. Alfa MJ, DeGagne P, Olson N, Puchalski T. Comparison of ion plasma, vaporized hydrogen peroxide, and $100 \%$ ethylene oxide sterilizers to the 12/88 ethylene oxide gas sterilizer. Infect Control Hosp Epidemiol 1996;17:92-100.

\title{
Pressure Ulcers: Impact on Hospital Costs and Length of Stay
}

\section{Gina Pugliese, RN, MS Martin S. Favero, PhD}

Allman and colleagues from the University of Alabama at Birmingham conducted a study to determine whether the development of a stage II or greater nosocomial pressure ulcer in-hospital is associated with increased hospital costs and length of stay after adjusting for admission severity of illness, comorbidities, nosocomial infections, and other hospital complications. The study included 286 patients identified within 3 days of admission, age 55 or greater, expected to be confined to bed or chair or with a hip fracture and expected to remain in hospital at least 5 days. Weekly skin assessments were performed by study nurses to document the development of pressure ulcers. Medical-record reviews, patient examinations, and physician and nurse interviews were used to obtain base- line demographic, medical, functional, nutritional, and global measures of disease severity. The incidences of nosocomial infections and other hospital complications were monitored by medical-record reviews. Hospital costs were estimated using category-specific cost-to-charge ratios.

Incident pressure ulcers were associated with significantly higher mean unadjusted hospital costs $(\$ 37,288$ vs $\$ 13,924, P=.0001)$ and length of stay (30.4 vs 12.8 days, $P=.0001)$. Patients who developed pressure ulcers also were more likely to develop nosocomial infections (45.9\% [17/37] vs $20.1 \%$ [50/249], $P=.001)$ and other hospital complications $(86.5 \% \quad[32 / 37]$ vs $43.0 \%$ $[107 / 249], P<.001)$. After adjusting for only the admission predictors of costs and length of stay by multivariable analyses, hospital costs and length of stay for those who devel- oped pressure ulcers remained significantly greater than for those who did not develop pressure ulcers ( $\$ 14,260$ vs $\$ 12,382, P=.03$, and 16.9 vs 12.9 days, $P=.02$, respectively). The differences in costs and length of stay for those with and without incident pressure ulcers were even greater when adjusted for admission predictors and also the occurrence of nosocomial infections and other complications $(\$ 29,048$ vs $\$ 13,819$, $P=.002$, and 20.9 vs 12.7 days, $P=.0001$, respectively). The authors concluded that incident pressure ulcers are associated with substantial and significant increases in hospital costs and length of stay.

FROM: Allman RM, Goode PS, Burst N, Bartolucci AA, Thomas DR. Pressure ulcers, hospital complications, and disease severity: impact on hospital costs and length of stay. $A d v$ Wound Care 1999;12:22-30. 